the norms of rational food and provide a full receipt of essential components while using muffin "Whoopi Pie" in the recommended amount.

Despite the effectiveness of this approach while developing the recipe composition of muffins at the phases of setting of objective functions and limits introduction some problems related to a wide range of proposed raw materials and local quality criteria arise. The applied research of generalized criterion of quality for determining the optimal balance factor and the content of limiting amino acids in the recipe.

\title{
References
}

[1] L. M. Telejenko et al, "Simulation of a balanced diet. Modelirovanie racionalnogo pitaniya" Oborudovanie I tehnologii pishevih proizvodstv: Zbornik nauchnih trudov DonNUET im. M. Tugan-Baranovskogo, vol. 30, pp. 306 - 311, 2013;

[2] N. A. Kushnir, "Osnovy tehnologii polucheniya kolagena iz rybnogo kologenosoderjashego syriya" Sovremennaya tehnika i tehnologii pishevyh proizvodstv restoranov I torgovli: Zbornik nauchnih trudov, vol. 1 (19) pp. 107-116, 2014;

[3] R.W. Moskowitz, "Role of collagen hydrolysate in bone and joint disease" Seminars in Arthritis and Rheumatism, vol. 30, pp. 87 - 99, 2000;

[4] Z.-Y. Liu et al., "Optimization of hydrolysis conditions for the production of the angiotensin-I converting enzyme inhibitory peptides from sea cucumber collagen hydrolysates".Journal of Aquatic Food Product Technology, vol. 20, is. 2 pp. 222 - 232, Apr. 2011;

[5] F. Liu et al. Evaluation of the antioxidant activity of collagen peptide additive extracted from cod skin. // Journal of Environment Protection and Ecology, vol.13, no. 3A, pp. 1836-1841, 2012;

[6] P. Yu and H. Chen, "Optimization of conditions for enzymatic production collagen hydrolysates from a long-value acaudinamolpadioides and their activites" Journal of Food Biochemistry, vol. 38, pp. 227-235, 2013;

[7] I.W. Browder, M.S. Litwin, "Use of absorbable collagen for hemostasis in general surgical patients" The American Journal of Surgery, vol. 52, no. 9, pp. 492 - 494, 1986;

[8] N. Dzyuba, "Identificaciya IK-spektroskopiey kompleksoobrazovaniya amilazy-glutena" Tovari i rynki, no. 2 (20), pp. 33-41, 2015;

[9] N. A. Kushnir, "Opredelenie sbalansirovannosti aminokislotnogo sostava kologennogo preporata" Sovremennaya tehnika i tehnologii pishevyh proizvodstv restoranov I torgovli: Zbornik nauchnih trudov, vol. 1 (19), pp. 117-126, 2014.

\section{THE PROJECT MANAGEMENT OF INDUSTRIAL BUILDINGS REENGINEERING (RECONSTRUCTION AND COMPLETION)}

\author{
K. Kolesnikova ${ }^{1}$, D. Monova ${ }^{2}$, Ye. Naumenko ${ }^{3}$, I. Kheblov ${ }^{4}$, I. Gurjev ${ }^{5}$ \\ $1,2,3,4,5$ Odessa national polytechnic university, Odessa \\ ORCID: 0000-0002-6844-1457 ${ }^{\text {; }}$ 0000-0001-5062-2949² ; 0000-0002-6963-3995 $;$; 0000-0003-0441-473X ${ }^{4}$; \\ 0000-0002-6014-153X $\mathrm{X}^{5}$ \\ E-mail: ne_takaya27@mail.ru ${ }^{3}$
}

Copyright (C 2014 by author and the journal “Automation technological and business - processes”. This work is licensed under the Creative Commons Attribution International License (CC BY). http://creativecommons.org/licenses/by/4.0/

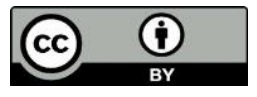

ONAFT

Open Access

Abstract: Creative element fate of any activity may not fall to zero because of the turbulent environment in which these activities are carried out, always prevents this. Environment that makes each building unique, that is, provides the main basis 
of the project. When we are talking about complex construction, the share of the creative component becomes very significant. First and foremost, this is explained by the duration of the construction work, during which time to happen risk events. The article analyses the processes of construction from the point of view of their conformity to the concept of project activities. It is shown that with increasing degree of difficulty of construction or time of the last share of creative activities in the overall project grows. In recent times more and more widespread work on re-engineering complex systems, for example, building constructions. This means repair of the building, but not a simple repair with restoration of the original, incorporated in the design of building elements and their interfaces, and partial or full replacement of items that fail or are outdated, new ones require first, a new design of their structures and production technologies, as well as the design of the accessories for the installation and technology is reshaping the object. Combining the two above-mentioned factors of growth of the share of creative activities during the project management of the re-engineering of building structures: complexity and construction time, received a cognitive model of such growth. Introduced the concept of "reengineering in construction" as a combination of the processes of adjustment and worn or completion of unfinished buildings. It is proved that any re-engineering in construction is the project activities. Provisions are tested in a real reengineering of industrial buildings with a positive technical and economic effect.

Анотація: Креативна складова доля будь-якої діяльності не може опускатися до нуля, оскільки турбулентне середовище, в якому ия діяльність здійснюється, завжди изьому заважає. Середовище робить кожне будівництво унікальним, тобто надає йому головної ознаки проекту. Коли ж мова йде про складне будівництво, частка креативної складової стає вельми значною. В першу чергу, ие пояснюється великим терміном будівельних робіт, під час якого встигають відбутися ризикові події. Проаналізовані процеси будівництва з точки зору їхньої відповідності поняттю проектна діяльність. Показано, щзо із підвищенням ступеня складності будівництва або термінів останнього частка креативної діяльності в загальному проекті зростає. Останнім часом все більшого поширення набувають роботи з реінжинірингу складних систем, наприклад, будівельних споруд. Це означає ремонт будівлі, але не простий ремонт із відбудовою початкових, закладених в проект будівлі елементів та їхніх сполучень, а часткову або повну заміну елементів, що вийшли з ладу або застаріли, на нові, які потребують спочатку нового проектування їх конструкиій та технологій виготовлення, а також конструкиій допоміжних вузлів для монтажу і технології саме перебудови об’єкта. Поєднуючи два згадані вище фактори зростання частки креативної діяльності під час управління проектом реінжинірингу будівельних споруд: складність та час будівництва, отримали когнітивну модель такого зростання. Введено поняття «реінжиніринг у будівництві» як поєднання процесів перебудови та добудови зношених або незакінчених будівель. Доведено, щзо будь який реінжиніринг у будівництві є проектною діяльністю. Розроблені положення випробувані у реальному реінжинірингу промислової будови із позитивним технікоекономічним ефектом.

Key words: Reengineering of building structures, rebuilding, completion, creative project activities.

Ключові слова: Реінжиніринг будівельних споруд, перебудова, добудова, креативна проектна діяльність.

1. Statement of a problem in a general view and its communication with important scientific or practical tasks.

In recent times more and more widespread work on reengineering complex systems, for example, building constructions are spreading. This means repair of the building, but not a simple repair with restoration of the original, incorporated in the design of building elements and their interfaces, and partial or full replacement of items that fail or are outdated, to new ones which require first, a new design of their structures and production technologies, as well as the design of the accessories for the installation and technology of reshaping the object. A similar problem arises when it is necessary to complete the construction, which has long stood unfinished for various reasons, and in this case, such a process requires the design and fabrication of the future design and technology of its completion new elements.

Such work is impossible to foresee - it is not known what will be revealed after this object disassemblers that is not known (or partially known with some probability) or items that you just have to restore (based on existing drawings and technology), nor items that require a whole new approach to their fabrication and installation. In such circumstances, even the Holy of holies of the project - its purpose can be adaptive - to change during the execution of the project, adapting to previously unknown internal and external circumstances.

2. The Analysis of the last researches and publications in which the solution of this problem is begun and to which the author, allocation of parts of a common problem unresolved earlier to which article is devoted.

In any case, the restructuring and completion of various structures requires mutch technical and economic support, which starts with the planning of future work.

Thus created plans, stickis with a turbulent environment, are subject to significant changes due to the increase of a creative component project activities [1] in the future management of similar projects is reduced to the latest risk management because risks are the main negative impacts on the implementation process [2].

To solve these problems, a special class of software - the scheduling and control of projects, or in other project management systems - then we will use this term [3].

Thus, these systems provide support for the main time of the process, resource and cost planning and control based on network planning algorithms, the critical path method (some even resource-critical), the method of earned value, and so on. 
Construction projects were at the origins of network planning. Actually the critical path method was developed to coordinate the work on the construction of factories of chemical concern "DuPont". Currently, an increasing number of construction companies begins to use the scheduling system to improve the efficiency of their work.

Project management systems can store in its model project targets of the project (time, cost, volume and so on) and enter the actual data in the course of the project. Of course, the original schedule "floats". But the system allows you to see these deviations, to assess their impact on the project as a whole, play and choose the best option reactions to change, reschedule the rest of the project, if necessary, to the new realities, quickly make changes to the project documentation. It is at this stage, the system shows its best qualities - a model of the "live" with a real project. The project manager gets their hands on a tool not only for monitoring historical facts, but also the opportunity to predict the future.

According to the State construction norms of Ukraine in the part operation of structures and engineering equipment of buildings and life support systems, and repair and reinforcement of load-bearing and enclosing structures and foundations of industrial buildings and structures [4] the most important stage of the life cycle of industrial structures is their operation in terms of risk environmental influences. When proper construction detects unacceptable levels of aging or wear, the use of the above mentioned gain is beyond repair and is, in fact, reengineering and so on the reorganization of the corresponding object. Such restructuring requires a very different approach to its planning and implementation - instead of construction management at the forefront of project management.

3. The Formulation of article purposes (problem definition).

The aim of this work was to improve the quality and reduce time and construction costs by identifying the need and application management reengineering construction methods and models of project management.

To achieve this objective the following tasks wear don:

- the processes of construction from the point of view of their conformity to the concept of "project management" wear analyzed;

- it is shown that with increasing degree of difficulty construction or time of the last share of creative activities in the overall process of managing construction project increases;

- the concept of "reengineering in construction" as a combination of the processes of adjustment and worn or completion of unfinished buildings, it is proved that any re-engineering in construction is a project-based activity was defined;

- in LLC "Gemoras" (Odessa) a production system "REBUS" optimization of support design decisions, as well as reducing the cost and terms of reengineering building structures projects, which showed that real reengineering industrial buildings with a positive technical and economic effect carried out.

4. The Statement of the main material of research with full justification of the received scientific results.

The life cycle of the construction starts with planning its design and manufacturing technology. In the process of such manufacture, depending on the complexity of the object increases the proportion of creative design activities (Fig. 1).

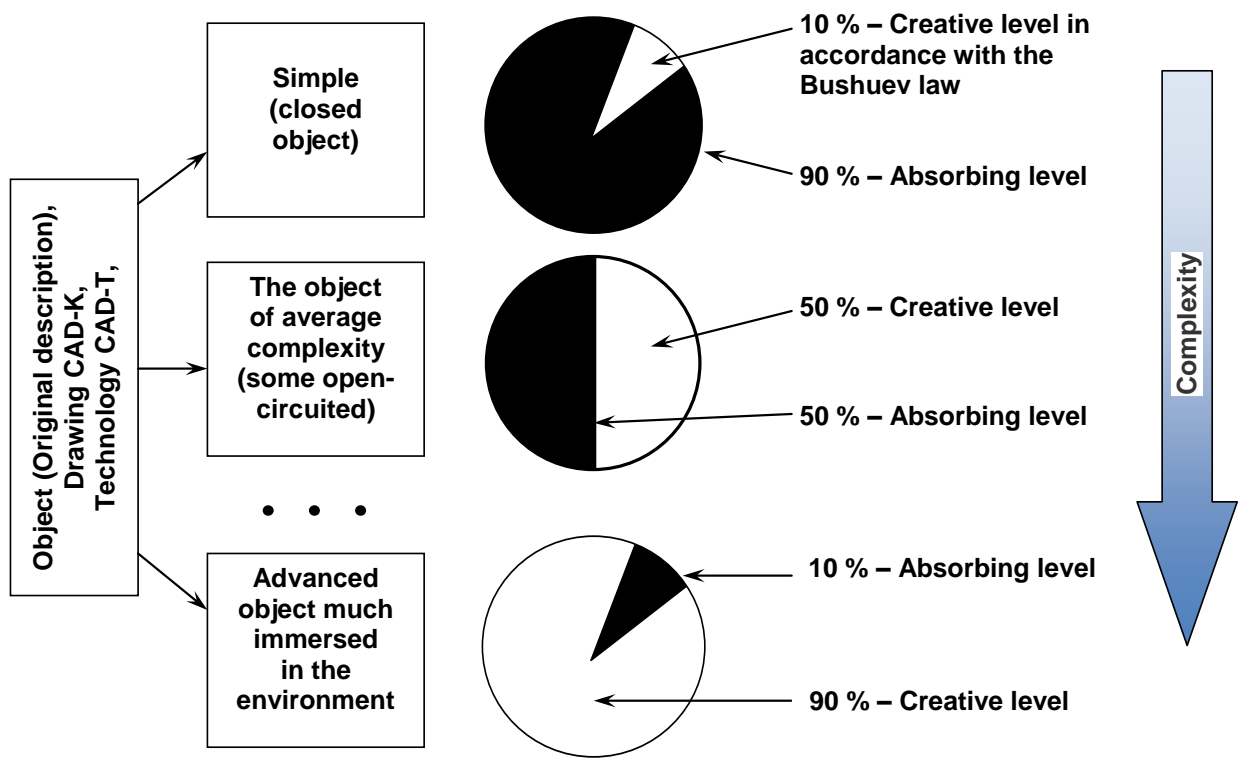

Fig. 1 - Increase in the share of creative project activities with the increasing complexity of construction works (percentages are as an example)

In order to the S.D. Bushuev law, creative part of any activity can not fall to zero, as the turbulent environment in which these activities are carried out, always prevents this way [5]. The environment makes each construction unique, that gives it the 
main features of the project. When it comes to complex, creative component of building share is very significant. Primarily, this is due to major construction period, during which is time to happen risk events.

Another factor, the growth of which leads to an increasing in the share of creative project work is the construction time (Fig. 2).

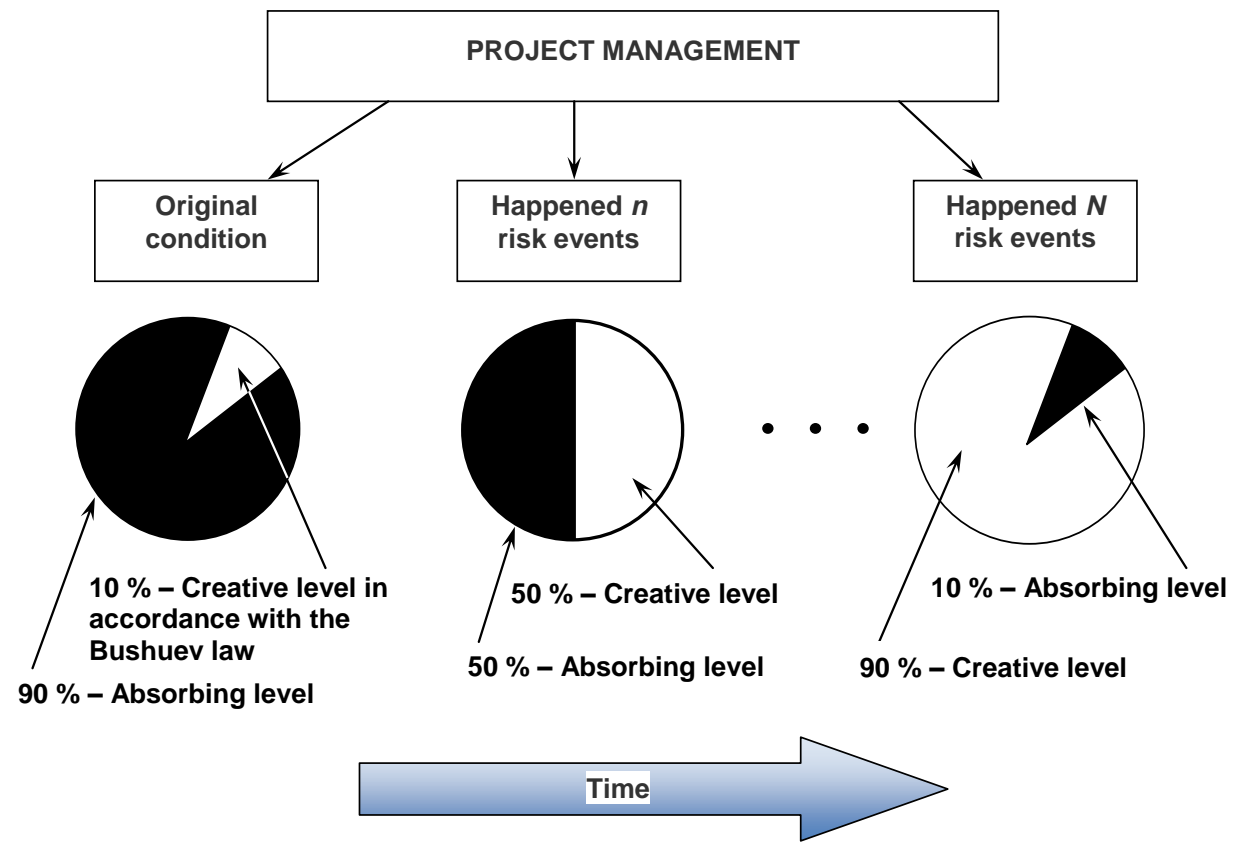

Fig. 2 - Increase in the share of creative project activity with increasing the time of construction work (percentages are as an example)

When there is an impact on the status of implementation of two different factors project construction, we can talk about skeletal the combination of the latter action result. In this case, certain factors reinforce each other and their total effect is greater than their separate effects. So, combining the two above-mentioned factors of the share growth creative activities during the project management of reengineering construction: the complexity and time of construction, the resulting cognitive model of such growth in the form shown in Fig. 3.

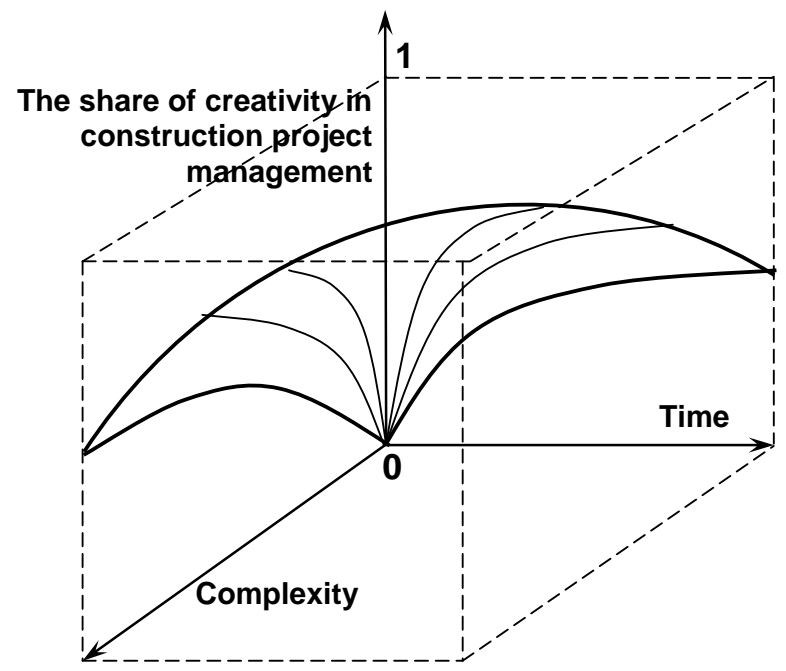

Fig. 3 - The cognitive skeletal model of the project management creativity increasing with the growth of construction time and its complexity

Construction growth may be due to the turbulent environment, the effect of which slows down the process. The slowdown may be brought to a complete cessation of construction and the probable renewal of it through a long time, for example, in a few years. In the latter case, it is not about the slow construction, and on completion of the building, whose construction was halted long ago. 
We will consider the case as one of the options for reengineering of the structure, because of its late completion can not be carried out at primary projects (because of the presence of new materials, construction technology, human resources, financial support, etc.) and requires a new engineering support: new design and new technologies. Remember that reengineering is a radical rethinking and redesigning of objects to achieve the sharp, abrupt improvements of the main indicators of their activity [6].

From the point of view of the need for new engineering support to the reengineering in the form of completion can be attributed to the restructuring of the buildings which, despite being operated or not, are morally and technically outdated and require a partial or full rebuild.

Thus, the reengineering understand the completion or redevelopment of buildings, which is not possible without changing the original design and construction technologies.

It is assumed that at the beginning of the completion and restructuring, much has changed in comparison with the beginning of construction of the primary (Fig. 4).

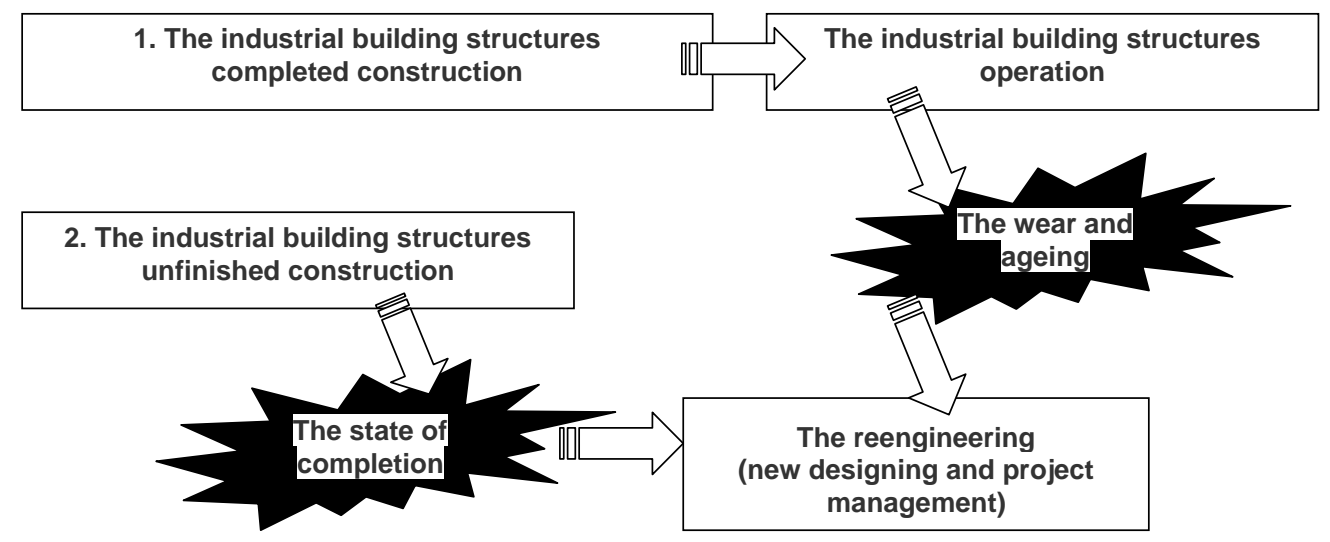

Fig. 4 - The changing of the turbulent environment design at the beginning of the reengineering building structures

These changes are not always obvious, they do not lie on the surface, and to detect them it is necessary not only to re-examine the environment that has changed significantly (the available funds, materials, suppliers, equipment, performers, legislation, etc.), but in the literal sense of "to disassemble" a building and see what condition remained hidden elements of the latter, for example, glass, metal fittings, wooden floors etc. After all, in this dismantling project Manager of reengineering tend to expect a "big surprise" - which in terms of project management risks, but the risks are not common, and the risk of surprises.

An example of such risks is given in the Fig. 5. During reconstruction of the Technical office of the plant [7] have been identified worn and damaged elements of the building which had once again to design and install. The list of such items has included items box at home: slabs, beams, etc., as well as windows, stairs, and other. In addition were replaced with modern sanitary-technical equipment, electrical equipment. Added internal computer network, video surveillance systems and communications. A complete upgrade of the house facade and adjoining territory performed.
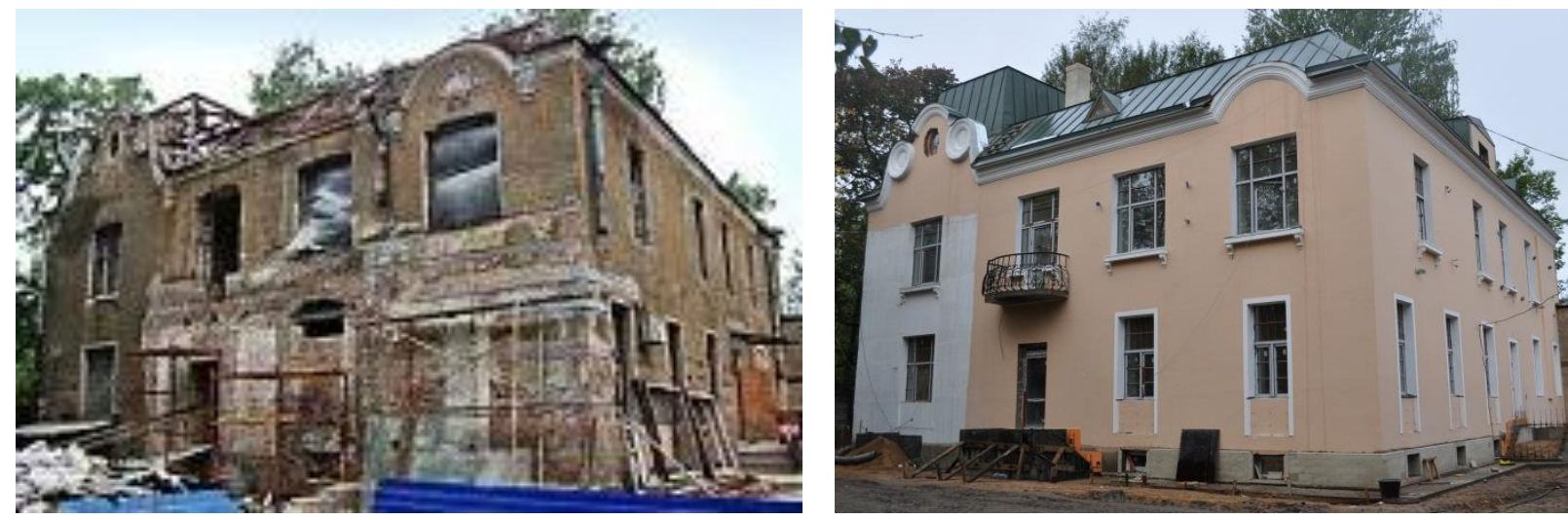

Fig. 5 - The reconstruction of the Technical office of the plant

The results of the study were used in the completion of industrial buildings in the form shown in Fig. 6, stood for five years. Thus, under the action of atmospheric moisture and stray currents corrupted by the metal reinforcements of the building, as well as some elements of the wall panels. 

www.journal-atbp.com
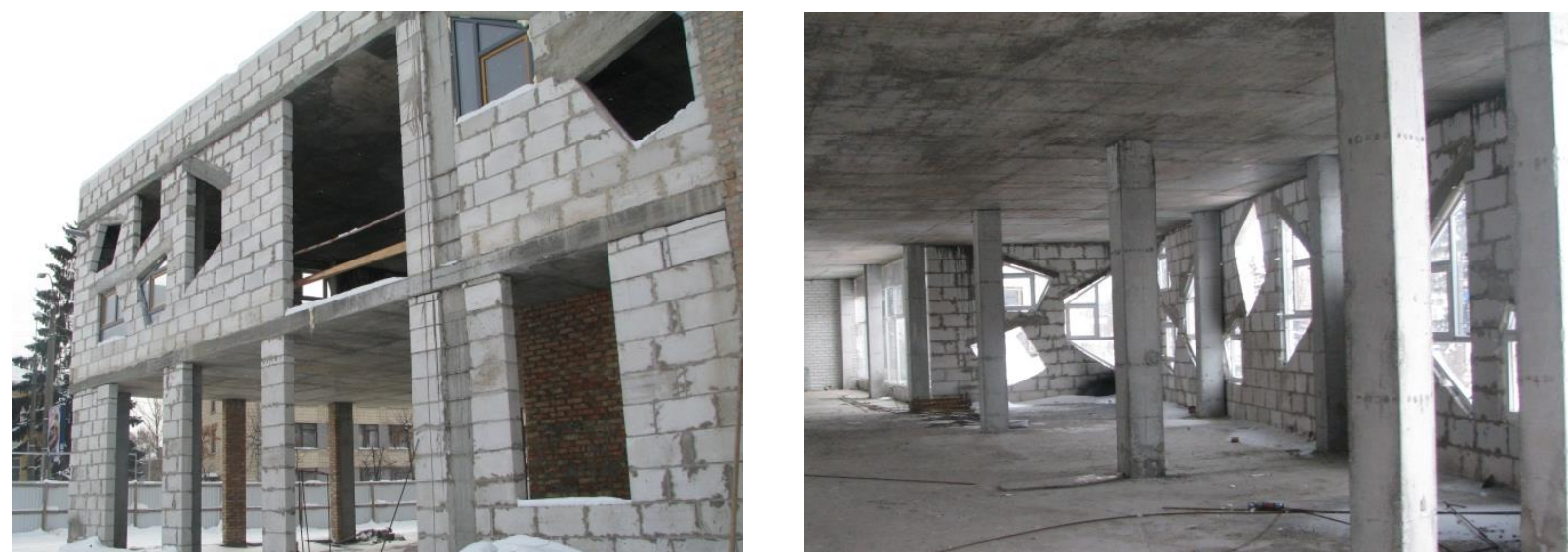

Fig. 6 - An External view of the house in Odessa to the beginning of completion

The continuation of the construction demanded a full update of the management plan for the project construction works, which included works associated with replacement of damaged elements and the completion of a new subject of modernization of electric engineering, ventilation, heating and other equipment up to modern requirements. In LLC "Gemoras" was tested the system "REBUS" optimization of support design decisions, as well as reducing the cost and terms of projects of reengineering of building structures. The system "REBUS" was involved to manage the project of the industrial facility facade reengineering with the aim of improving its ventilation and lighting characteristics.

The result of this reengineering is shown in Fig. 7.
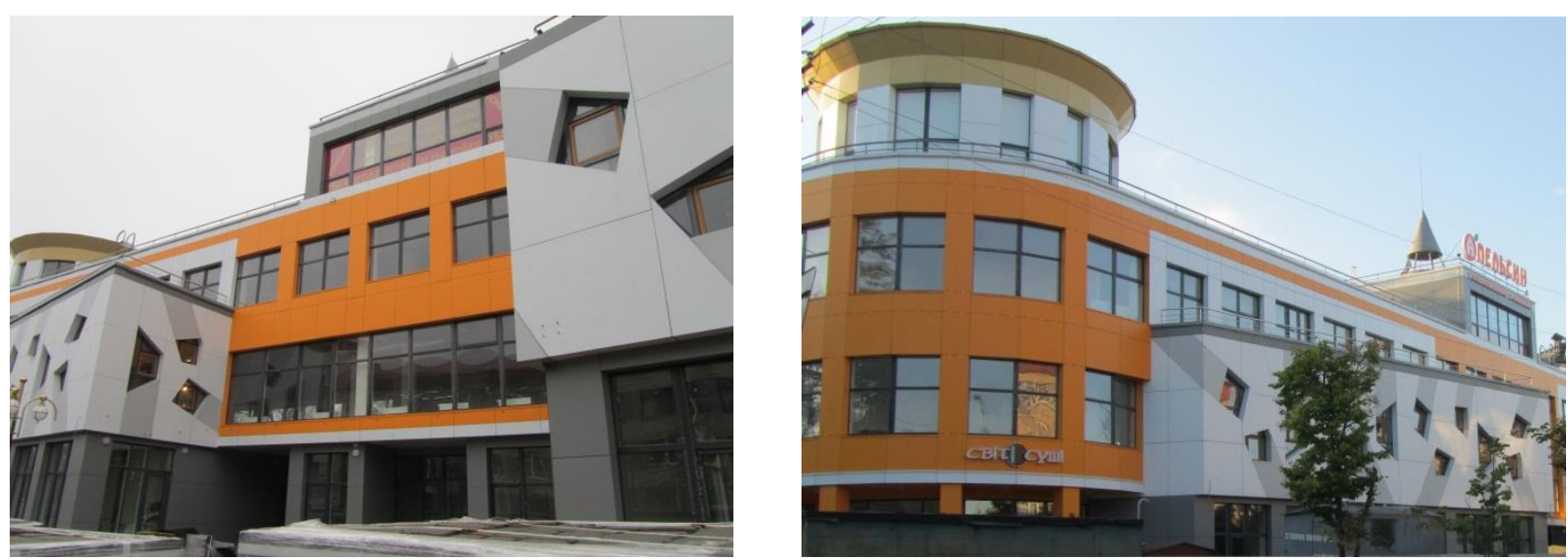

Fig. 7 - An External view of the house in Odessa after the completion

The system "REBUS" showed that its use allowed to achieve the following technical and economic results:

- with respect to the interaction with the turbulent environment: developed standards of operations of the management of the project as a response to changes in planned early in the project functional areas of project activities;

- with respect of the project management process: reduced installation costs by 1,3 times; reduced the term of the warehouse space lease by $18 \%$; increased speed of information processing in the logistics department by $7 \%$;

- in terms of the product project: insolation is the most darkened areas of the room increased by almost $40 \%$; total costs for heating of the object has decreased by $26,6 \%$ while maintaining the average temperature in the premises; the amount of carbon monoxide (CO) in the air in the internal volume of construction decreased by $27,1 \%$.

5. Conclusions on this research and prospects of further development in this direction.

The analysis of the construction process found that even in a simple at a relatively fast building always has a share of creative activities, which corresponds to the "projects management" process. With the increased complexity of construction or the time of the last such share of creative activities in the overall process of managing construction project increases.

Especially, this growth is observed, when it comes to the completion of long-abandoned buildings or on the restructuring of obsolete or worn out. Define the concept of "reengineering in construction" as a combination of the processes of adjustment and worn or completion of unfinished buildings, it is proved that any re-engineering in construction is the project activities.

\section{References}

[1] Kolesnikova, E. V., Stanovskaya, I. I. (2013). Metodyi kolichestvennoy otsenki stepeni transformatsii seriynoy proektnoy deyatelnosti $\mathrm{v}$ operatsionnuyu. Informatsiyni tehnologiyi v osviti, nautsi ta virobnitstvi: zbirrnyk naukovih prats, Odesa, Bahva, 4(5), $32-40$; 
[2] V. N. Urodovskih, Upravlenie riskami predpriyatiya. M.:Vuzovskiy uchebnik: INFRA-M, 2012;

[3] A.Griffit, Sistemyi upravleniya v stroitelstve. Samara: Olimp-Biznes, 2006;

[4] DBN V.3.1-1-2002. (2003). Derzhavni budivelni normy Ukrayiny. Ekspluatatsiya konstruktsiy ta inzhenernogo obladnannya budivel i sporud ta sistem zhittEzabezpechennya. Remont i pidsilennya nesuchih i ogorodzhuvalnih budivelnih konstruktsiy i osnov promislovih budinkiv ta sporud. Derzhavniy komitet Ukrayini z budivnitstva i arhitekturi, 56;

[5] Gogunskiy, V. D., Stanovskaya, I. I., Gurev, I. N. (). Zakon Bushueva - garantiya nepolnoy transformatsii seriynyih proektov v operatsionnuyu deyatelnost. Vostochno-evropeyskiy zhurnal peredovyih tehnologiy. Informatsionnyie tehnologii, Harkov, 4/3 (64), 41 - 44;

[6] Barinov, V. A. (2016). Reinzhiniring: suschnost i metodologiya / Elitarium. Available http://www.ippnou.ru/print/002369/;

[7] Kontora Tehnohimicheskogo zavoda poligraficheskoy kraski i lakov (2016). Available: <http://baltstroi.ru/ru/proekty/kontora_tehnohimicheskogo_zavoda/>.

Література

[1] Е. В. Колесникова, И. И. Становская, "Методы количественной оценки степени трансформации серийной проектной деятельности в операционную,” Інформаційні технології в освіті, науиі та виробнищтві: збірник наукових пращь, вип. 4(5), сс. 32 - 40, 2013;

[2] В. Н. Уродовских, Управление рисками предприятия. М.: Вузовский учебник, ИНФРА-М, 2012;

[3] А. Гриффит, Системы управления в строительстве. Самара: Олимп-Бизнес, 2006;

[4] ДБН В.3.1-1-2002. Державні будівельні норми України. Експлуатація конструкцій та інженерного обладнання будівель і споруд та систем життєзабезпечення. Ремонт і підсилення несучих і огороджувальних будівельних конструкцій і основ промислових будинків та споруд. - К.: Державний комітет України з будівництва i архітектури, 2003. - $56 \mathrm{c}$;

[5] В. Д. Гогунский и др., “Закон Бушуева - гарантия неполной трансформации серийных проектов в операционную деятельность” Восточно-европейский журнал передовых технологий. Информационные технологии, по. 4/3 (64), сс. $41-44,2013$;

[6] В. А. Баринов, (19, June 2006). “Реинжиниринг: сущность и методология” Элитариум [Онлайн]. Режим доступа: http://www.ippnou.ru/print/002369/. [Доступно: Октябрь 8, 2016];

[7] Балт Строй. "Контора Технохимического завода полиграфической краски и лаков," balt-stroi.ru.[Онлайн]. Режим доступа: http://balt-stroi.ru/ru/proekty/kontora_tehnohimicheskogo_zavoda/. [Доступно: Июль 14, 2016].

\title{
AUTOMATIC REGULATOR FOR NON-STATIONARY OBJECTS WITH AN INCREASED RANGE OF NORMAL OPERATION
}

\author{
A. I. Pavlov ${ }^{1}$ \\ ${ }^{1}$ Odessa National Academy of food technologies, Odessa \\ Copyright (C 2014 by author and the journal “Automation technological and business - processes". \\ This work is licensed under the Creative Commons Attribution International License (CC BY). \\ http://creativecommons.org/licenses/by/4.0/
}

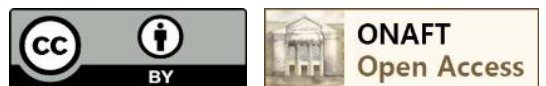

Abstract: Many objects automatic control unsteady. This is manifested in the change of their parameters. Therefore, 